
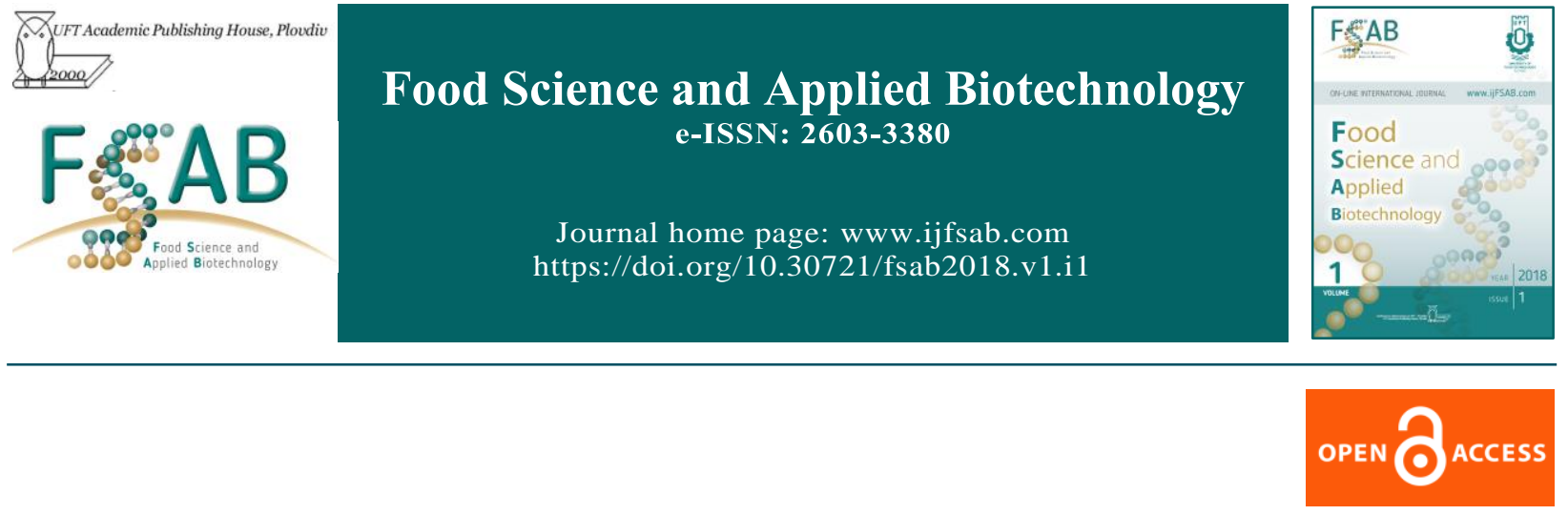

Research Article

\title{
Amperometric sensing of hydrogen peroxide using glassy carbon electrode modified with rhodium
}

\author{
Yanna Lazarova $^{1}$ and Totka Dodevska ${ }^{1 \boxminus}$ \\ ${ }^{1}$ University of Food Technologies, Department of Organic chemistry and Inorganic chemistry
}

\begin{abstract}
Following our previous studies on the catalytic activity of electrochemically deposited on glassy carbon $\mathrm{Rh}$ electrocatalyst towards the reduction of hydrogen peroxide $\left(\mathrm{H}_{2} \mathrm{O}_{2}\right)$, the electrochemical behaviour of the modified electrode was studied by means of cyclic voltammetry and chronoamperometry at $\mathrm{pH}$-values from 5.0 to 9.0. The modified electrode exhibited a rapid, sensitive and reproducible response for the quantitative determination of $\mathrm{H}_{2} \mathrm{O}_{2}$ at low applied potential. Amperometry carried out at constant potential of $0 \mathrm{~V}(\mathrm{vs} . \mathrm{Ag} / \mathrm{AgCl}, 3 \mathrm{M} \mathrm{KCl})$ at $\mathrm{pH} 6.0\left(25^{\circ} \mathrm{C}\right)$ gave the following operational parameters: detection limit of $4 \mu \mathrm{M}$, linear dynamic range $0.01-5.5 \mathrm{mM}$ and electrode sensitivity of $377 \mu \mathrm{A} \mathrm{mM}{ }^{-1}$ $\mathrm{cm}^{-2}$.
\end{abstract}

Keywords: amperometric sensor, rhodium, electrodeposition, hydrogen peroxide reduction

\author{
Abbreviations: \\ GC - glassy carbon \\ CV - cyclic voltammetry \\ RSD - relative standard deviation
}

$\square$ Corresponding author: Totka Mihaylova Dodevska, Associate Professor, PhD; Department of Organic chemistry and Inorganic chemistry, Technological Faculty, University of Food Technologies, 26 Maritsa Blvd., Plovdiv 4002, Bulgaria, +35932603679, E-mail: dodevska@mail.bg

Article history:

Received 16 October 2017

Reviewed 18 January 2018

Accepted 19 January 2018

Available on-line 14 March 2018

https://doi.org/10.30721/fsab2018.v1.i1.4 (C) 2018 The Authors. UFT Academic publishing house, Plovdiv 


\section{Introduction}

The studies of the deposition of micro- and nanosized strutrures of rhodium (Rh) are motivated by the well-known catalytic activity of this metal and its extreme resistivity towards acids and bases, rendering $\mathrm{Rh}$-structures broadly applicable and potentially aging resistant. Rh shows outstanding catalytic properties in various reactions such as the reduction of nitrate and nitrite ions (Casella et al. 2014), hydrogenation of $\mathrm{CO}, \mathrm{CO}_{2}$, alkenes and arenes (García et al. 2014; Park et al. 2007), C-C cross-coupling (Kanaru et al. 2009), decomposition of methane and some oxidation reactions (Ortiz et al. 2006; Horozova et al. 2008; Yuan et al. 2010; Sathe et al. 2011). Rh is an excellent catalyst in $(\mathrm{NO})_{\mathrm{x}}$ removal (Beyer et al. 2010), so it is a common component of the three-way catalyst used for the simultaneous conversion of nitrogen oxides, $\mathrm{CO}$ and hydrocarbons in automobile exhausts.

In our previous studies it was established that the electrochemical behaviour of the Rh-modified electrodes significantly depends on the nature of the carbonaceous carrier (Dodevska et al. 2016). In the target reaction (reduction of $\mathrm{H}_{2} \mathrm{O}_{2}$ ) the electrode based on glassy carbon possesses more than two-fold higher catalytic activity in comparison with the modified spectroscopic graphite. In the present work we studied Rhmodified glassy carbon, developed by using simple electrochemical deposition method, as a sensing element in the amperometric detection of $\mathrm{H}_{2} \mathrm{O}_{2}-$ industrially and biologically relevant analyte. $\mathrm{H}_{2} \mathrm{O}_{2}$ is used as an oxidizing and bleaching agent in the pharmaceutical, cosmetic, textile and paper industries; in the food industry $\mathrm{H}_{2} \mathrm{O}_{2}$ is used in the artificial aging of wines and as a sterilizing agent in the dairy industry; in medicine the excess of $\mathrm{H}_{2} \mathrm{O}_{2}$ in human body is associated with oxidative stress, aging, cancer and progressive neurodegenerative diseases. Moreover, the development of effective materials with defined operational parameters for quantitative determination of $\mathrm{H}_{2} \mathrm{O}_{2}$ at low potentials is relevant not only for the establishment of amperometric analysis of $\mathrm{H}_{2} \mathrm{O}_{2}$, but also for developing selective first generation biosensors.

\section{Materials and Methods}

The working electrode was a disc from glassy carbon (GC) with diameter of the working surface $3 \mathrm{~mm}$ and visible surface area of ca. $7.07 \mathrm{~mm}^{2}$ (Metrohm). $\mathrm{RhCl}_{3} \cdot \mathrm{nH}_{2} \mathrm{O}, \mathrm{HCl}, \mathrm{H}_{2} \mathrm{O}_{2}(30 \%$ (v/v) aqueous solution), $\quad \mathrm{Na}_{2} \mathrm{HPO}_{4} \cdot 12 \mathrm{H}_{2} \mathrm{O}$, $\mathrm{NaH}_{2} \mathrm{PO}_{4} \cdot 2 \mathrm{H}_{2} \mathrm{O}$ were purchased from Fluka. All chemicals used were of analytical grade. 0.1 M phosphate buffer solution (PBS) was made of sodium phosphates (monobasic and dibasic) dissolved in double distilled water with $\mathrm{pHs} 5.0-$ 9.0 adjusted with $\mathrm{H}_{3} \mathrm{PO}_{4}$ and $\mathrm{NaOH}$ using a $\mathrm{pH}$ meter MS2006 (Microsyst, Bulgaria). Double distilled water was used to prepare aqueous solutions.

Apparatus and measurements. The electrochemical measurements were performed using computer controlled electrochemical workstation EmStat2 (PalmSens BV, The Nederland), equipped with PSTrace 2.5.2 licensed software, in a conventional thermostated threeelectrode cell, including a working electrode (modified with rhodium GC electrode), an $\mathrm{Ag} / \mathrm{AgCl}(3 \mathrm{M} \mathrm{KCl})$ reference electrode, and a platinum auxiliary electrode.

All the electrochemical measurements were carried out at a temperature of $25^{\circ} \mathrm{C}$. To remove oxygen, the background solution was purged with pure argon. Cyclic voltammograms (CVs) were recorded at scan rates from 10 to $100 \mathrm{mV} \mathrm{s}^{-1}$. Peak intensities of CVs were reported with baseline correction. The amperometric experiments (calibrations) were performed by successive addition of aliquots of $3.10^{-2} \mathrm{M} \mathrm{H}_{2} \mathrm{O}_{2}$ solution to background electrolyte (0.1 M PBS) in the cell (30 $\mathrm{mL}$ initial volume) with simultaneous registration of the current at a constant potential. The $\mathrm{H}_{2} \mathrm{O}_{2}$ stock solution was freshly prepared before each measurement.

The experimental data were processed by software package 'OriginPro 8'.

Electrochemical deposition of Rh. Before modification, the GC electrode surface was carefully polished with 0.3 and $0.5 \mu \mathrm{m}$ alumina slurry on a polishing cloth (LECO, USA), followed by sonication in double distilled water for $3 \mathrm{~min}$. 
After bath sonication, the electrode was rinsed with double distilled water and allowed to dry at room temperature for few minutes. The rhodium was electrodeposited onto the clean working surface of the GC electrode by means of $\mathrm{CV}-1$ cycle at a scan rate of $100 \mathrm{mV} \mathrm{s}^{-1}$ from electrolyte containing $2 \% \mathrm{RhCl}_{3}$, dissolved in $0.1 \mathrm{M} \mathrm{HCl}$. The electrode surface was seeded with rhodium particles when starting the cycle at $-0.3 \mathrm{~V}$, then the scan goes up to 0.9 and back to $-0.3 \mathrm{~V}$. The modified $\mathrm{Rh} / \mathrm{GC}$ was subsequently rinsed twice with double distilled water, dried at ambient conditions and employed for the electrochemical studies.

\section{Results and Discussions}

Cyclic voltammetry (CV) was used to characterize the modified electrode. The presence of $\mathrm{Rh}$ deposits on the glassy carbon carrier was confirmed by the cyclic voltammogram, recorded in an electrolyte, $\mathrm{H}_{2} \mathrm{SO}_{4}$. Fig. 1 shows the $\mathrm{CV}$ of modified electrode $\mathrm{Rh} / \mathrm{GC}$ registered in $0.1 \mathrm{~N}$ $\mathrm{H}_{2} \mathrm{SO}_{4}$ in the potential range from -0.3 to $1.0 \mathrm{~V}$ at scan rate of $100 \mathrm{mV} \mathrm{s}^{-1}$. The characteristics (i.e. the attribution of observed peaks) of the $\mathrm{CV}$ for $\mathrm{Rh} / \mathrm{GC}$ in sulphuric acid are comparable as those of polycrystalline rhodium (Jerkiewicz et al. 1994) and electrodeposited mesoporous Rh film (Bartlett et al. 2003).

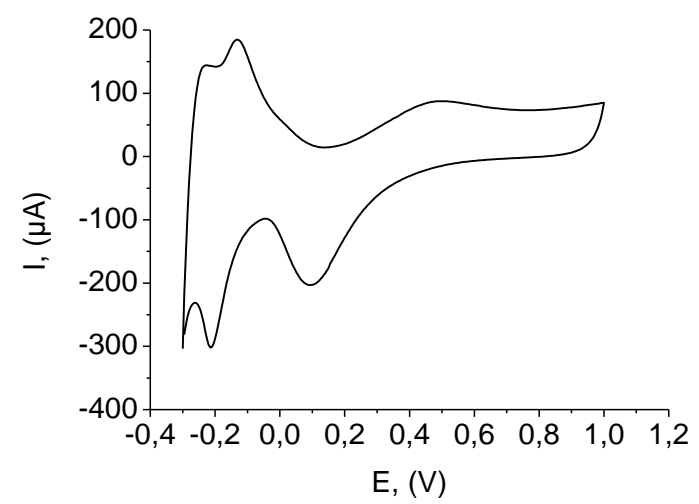

Figure 1. Cyclic voltammogram (CV) of modified electrode $\mathrm{Rh} / \mathrm{GC}$; supporting electrolyte $0.1 \mathrm{~N}$ $\mathrm{H}_{2} \mathrm{SO}_{4}$ (deaerated); scan rate of $100 \mathrm{mV} \mathrm{s}^{-1}$; reference electrode $\mathrm{Ag} / \mathrm{AgCl}, 3 \mathrm{M} \mathrm{KCl}$; temperature $25^{\circ} \mathrm{C}$.
According to the literature data (Jerkiewicz et al. 1994), different surface oxide films on $\mathrm{Rh}$ grow with increasing applied anodic potential. The formation of oxide film begins at around $0.2 \mathrm{~V}$ on the anodic scan. This process involves electrochemisoprtion of one monolayer of $\mathrm{OH}^{-}$and leads to the formation of $\mathrm{Rh}(\mathrm{OH})$ species. At higher anodic potentials (at about $0.8 \mathrm{~V}$ ) further oxidation and formation of $\mathrm{Rh}(\mathrm{OH})_{3}$ species occurs. Reversing the sweep direction towards more negative potentials (from 1.0 to $-0.3 \mathrm{~V}$ ) it can be observed that there is a single stripping peak associated to surface oxide reduction. The position of the stripping peak for Rh-electrodes is known to be sensitive to the anodic scan limit, acid concentration and the scan rate (Pallotta et al. 1981; Villard et al. 1997); under the chosen experimental conditions the stripping peak occurs at potential of $0.1 \mathrm{~V}$.

Oxide formation proceeds in three distinguishable stages and the reduction in two steps, accordingly to the following oxide formation-reduction scheme:

Oxidation:

$$
\begin{aligned}
& R h+\mathrm{H}_{2} \mathrm{O} \rightarrow \mathrm{Rh}(\mathrm{OH})+H^{+}+e^{-} ;(0.55-0.95 \mathrm{~V} v \mathrm{R} . \mathrm{RHE}) \\
& \mathrm{Rh}(\mathrm{OH})+2 \mathrm{H}_{2} \mathrm{O} \rightarrow \mathrm{Rh}(\mathrm{OH})_{3}+2 \mathrm{H}^{+}+2 e^{-} ;(0.95-1.4 \mathrm{~V})
\end{aligned}
$$

At potentials above $1.4 \mathrm{~V}$ (vs. RHE) authors (Jerkiewicz et al. 1994) proposed the formation of $\mathrm{RhO}(\mathrm{OH})$ species:

$2 \mathrm{Rh}(\mathrm{OH})_{3}+\mathrm{Rh} \rightarrow 3 \mathrm{RhO}(\mathrm{OH})+3 \mathrm{H}^{+}+3 e^{-} ;(>1.4 \mathrm{~V})$

Reduction:

$$
\begin{aligned}
& 3 \mathrm{RhO}(\mathrm{OH})+3 \mathrm{H}^{+}+3 e^{-} \rightarrow 2 \mathrm{Rh}(\mathrm{OH})_{3}+\mathrm{Rh} \\
& \mathrm{Rh}(\mathrm{OH})_{3}+3 \mathrm{H}^{+}+3 e^{-} \rightarrow \mathrm{Rh}+3 \mathrm{H}_{2} \mathrm{O}
\end{aligned}
$$

Continuing the cathodic scan, the current peak at $0.21 \mathrm{~V}$ is associated with the formation of a layer of adsorbed hydrogen at the electrode surface, which then is stripped from the surface at $-0.13 \mathrm{~V}$ on the anodic scan.

The successful modification of the glassy carbon carrier is also evidenced by $\mathrm{CV}$ recorded in buffer 
solution. The cyclic voltammograms of the bare GC electrode and of the rhodium-modified GC electrode were obtained in $0.1 \mathrm{M}$ PBS with $\mathrm{pH} 7.0$ (Fig. 2). No redox peak is observed on the CV of bare GC electrode (enlarged in inset plot). Compared with bare GC electrode, the background current of modified electrode is apparently larger, which indicates that the effective electrode surface area is significantly enhanced.

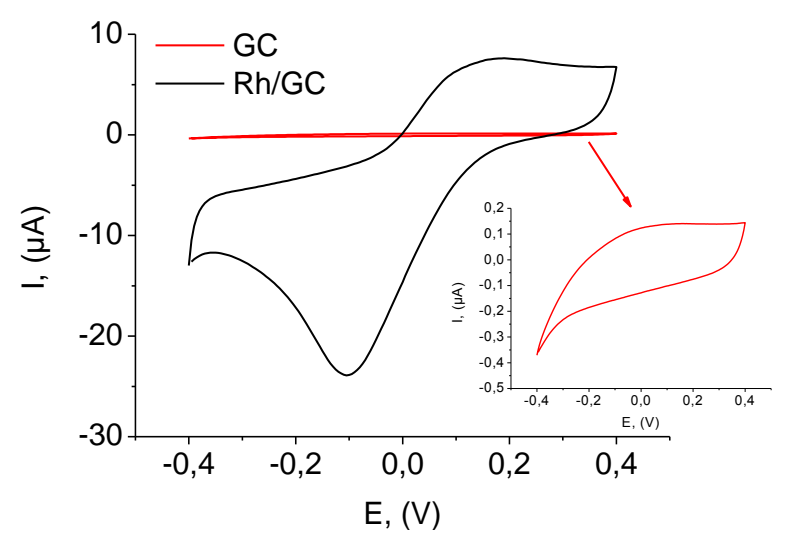

Figure 2. CVs of the bare glassy carbon electrode (red line) and of the rhodium-modified glassy carbon electrode (black line) recorded in $0.1 \mathrm{M}$ PBS ( $\mathrm{pH} \mathrm{7.0);} \mathrm{scan} \mathrm{rate} \mathrm{of} 50 \mathrm{mV} \mathrm{s}^{-1}$; reference electrode $\mathrm{Ag} / \mathrm{AgCl}, 3 \mathrm{M} \mathrm{KCl}$; temperature $25^{\circ} \mathrm{C}$.

In the next step, rhodium-modified GC was employed for the different scan rate studies in $\mathrm{pH}$ 7.0 PBS. Fig.3a clearly shows that all the anodic and cathodic peak currents of $\mathrm{Rh} / \mathrm{GC}$ increase linearly with respect to the scan rate in the range of $10-100 \mathrm{mV} \mathrm{s}^{-1}$. In Fig. $3 \mathrm{~b}$ is presented the plot of anodic and cathodic peak currents versus the scan rate. The linear regression equation (inset) for the anodic peak current was $\mathrm{I}_{\mathrm{p}, \mathrm{a}}(\mu \mathrm{A})=0.08561 \mathrm{v}(\mathrm{mV}$ $\left.\mathrm{s}^{-1}\right)+0.94942, \mathrm{R}^{2}=0.999$ and for the corresponding cathodic peak current was $\mathrm{I}_{\mathrm{p}, \mathrm{c}}(\mu \mathrm{A})$ $=-0.17968 \mathrm{v}\left(\mathrm{mV} \mathrm{s}^{-1}\right)-6.20754, \mathrm{R}^{2}=0.977$, respectively. The linear increase in the anodic and cathodic peak currents of modified $\mathrm{Rh} / \mathrm{GC}$ electrode according to the scan rate illustrates that the proposed rhodium deposit was stable and exhibits surface controlled thin-layer electrochemical behavior. In order to obtain prior information about the catalytic activity of the electrode towards the electroreduction of hydrogen peroxide, an amperometric response was recorded in the presence of $0.5 \mathrm{mM}$ and $1.0 \mathrm{mM} \mathrm{H}_{2} \mathrm{O}_{2}$ at a constant potential of $0 \mathrm{~V}$ in buffer solutions with $\mathrm{pH}$-values 5.0, 6.0, 7.0, 8.0 and 9.0.

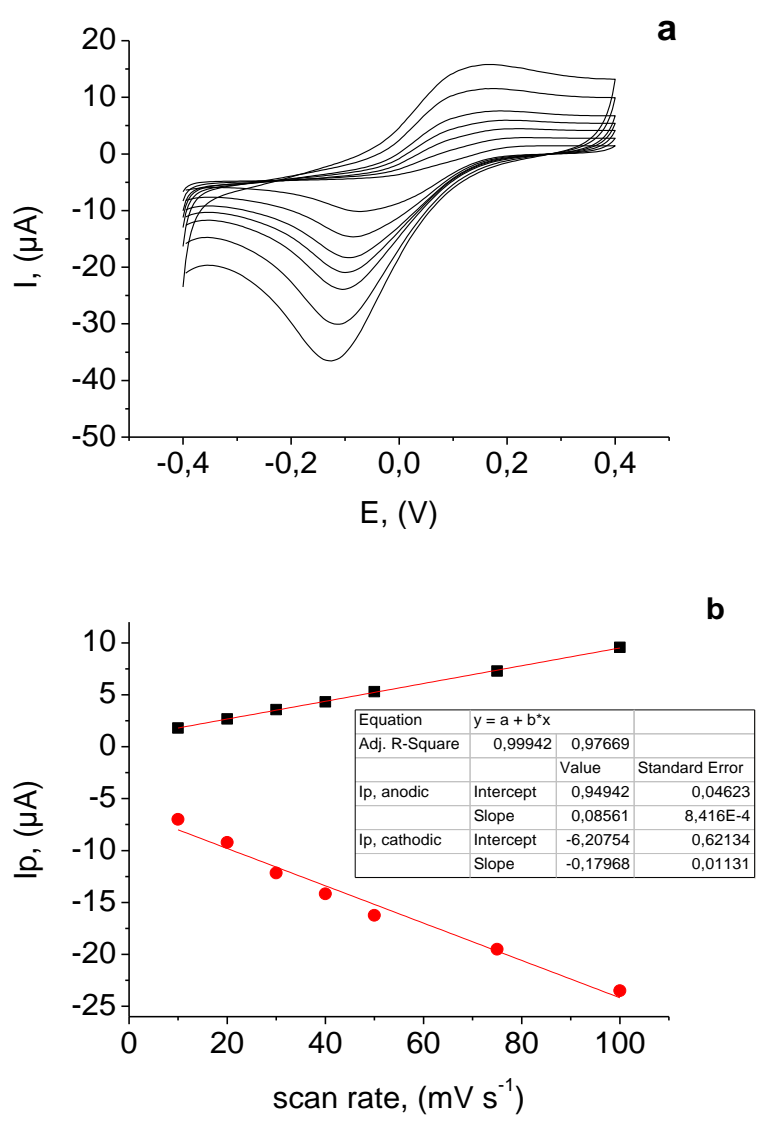

Figure 3. (a) CVs of modified electrode $\mathrm{Rh} / \mathrm{GC}$ in $0.1 \mathrm{M}$ PBS (pH 7.0) at different scan rates $(10,20$, 30, 40, 50, 75 and $100 \mathrm{mV} \mathrm{s}^{-1}$ ); (b) Plot of peak currents versus the scan rate; reference electrode $\mathrm{Ag} / \mathrm{AgCl}, 3 \mathrm{M} \mathrm{KCl}$; temperature $25^{\circ} \mathrm{C}$.

Cathode currents in presence of $\mathrm{H}_{2} \mathrm{O}_{2}$, resulting from its electrochemical reduction, were observed in the whole investigated $\mathrm{pH}$-range. Upon addition of $\mathrm{H}_{2} \mathrm{O}_{2}$ the $\mathrm{Rh} / \mathrm{GC}$ electrode shows increasing reduction currents (staircase current response), corresponding to the electrochemical conversion of the analyte.

The background subtracted steady-state response (Is-Io) of the electrode, registered in this study, is presented in Fig. 4. As shown, the current response decreased rapidly in alkaline medium. With increasing the $\mathrm{pH}$ from 7.0 to 8.0 , there was a 
sharp decline in the electrode response. From the experimental data it is seen that lowering the intensity of the current is almost $70 \%$. The electrode response, registered at $\mathrm{pH} 9.0$ is almost $88 \%$ lower than that recorded at $\mathrm{pH} 7.0$. At the same time, the lowering of the $\mathrm{pH}$ below 7.0, does not affect significantly the electrode response, and its value is very close to the one registered at $\mathrm{pH}$ 6.0 and $\mathrm{pH}$ 5.0.

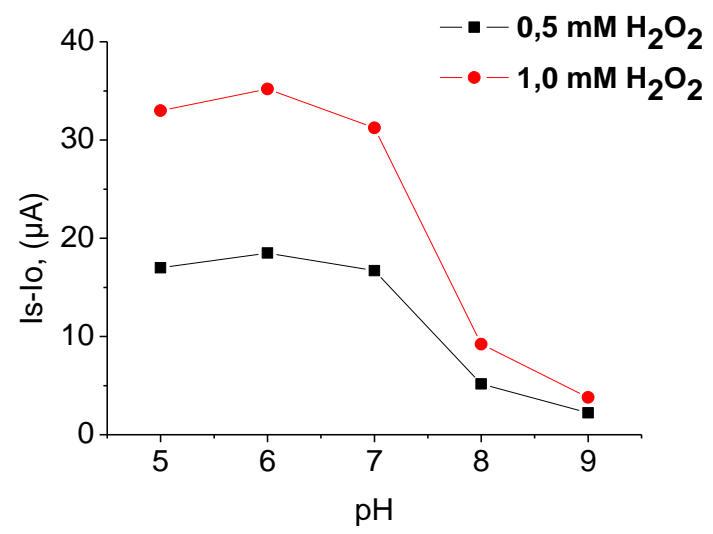

Figure 4. Effect of $\mathrm{pH}$ on the response of modified electrode $\mathrm{Rh} / \mathrm{GC}$ in presence of $0.5 \mathrm{mM} \mathrm{H} \mathrm{H}_{2}$ (black) and $1.0 \mathrm{mM} \mathrm{H} \mathrm{H}_{2}$ (red); applied potential of $0 \mathrm{~V}$; electrolyte $0.1 \mathrm{M} \mathrm{PBS}$; temperature $25^{\circ} \mathrm{C}$.

The effect of the $\mathrm{pH}$ on the operational parameters, in terms of electrode sensitivity and linear dynamic range, of the modified electrode was also investigated. Fig. 5a shows the typical current-time (I-t) plot upon the successive injection of $\mathrm{H}_{2} \mathrm{O}_{2}$ in PBS with $\mathrm{pH}$ 6.0. A well-defined response was observed during the successive additions of 0.01 $\mathrm{mM} \mathrm{H}_{2} \mathrm{O}_{2}$, which evidences a stable and efficient catalytic property of rhodium. It can also be observed that the modified electrode responds rapidly to the changes of $\mathrm{H}_{2} \mathrm{O}_{2}$ concentration, producing steady- state signal within $8 \mathrm{~s}$. The corresponding calibration curve is presented in Fig. $5 \mathrm{~b}$. The linear response was proportional to the $\mathrm{H}_{2} \mathrm{O}_{2}$ concentration up to $5.5 \mathrm{mM}$ (correlation coefficient of 0.987 ) with a sensitivity of $377 \mu \mathrm{A}$ $\mathrm{mM}^{-1} \mathrm{~cm}^{-2}$ and a detection limit of $4 \mu \mathrm{M}$ (at a signal-to-noise ratio of 3 ). The reproducibility of the current signal for the modified electrode to 970 $\mu \mathrm{M} \mathrm{H} \mathrm{H}_{2} \mathrm{O}_{2}$ was also examined in $0.1 \mathrm{M}$ PBS ( $\mathrm{pH}$ 6.0 ) - the relative standard deviation (RSD) was calculated $3.7 \%$ for five successive measurements (current responses were 35.25, 33.55, 36.60, 34.20 and $36.30 \mu \mathrm{A}$, respectively).

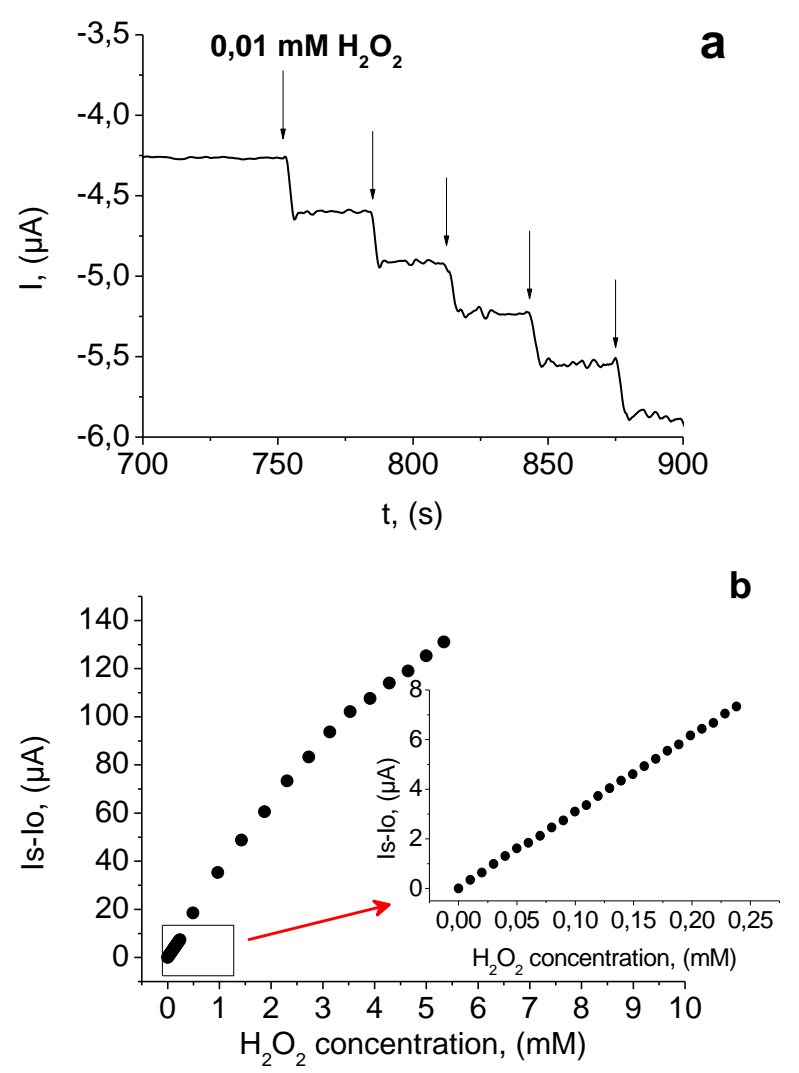

Figure 5. (a) Authentic record of the amperometric response of a modified electrode $\mathrm{Rh} / \mathrm{GC}$ in $0.1 \mathrm{M}$ PBS (pH 6.0) at potential of $0 \mathrm{~V}$ upon additions of $0.01 \mathrm{mM} \mathrm{H}_{2} \mathrm{O}_{2} ;$ b) Dependence of the amperometric response on the concentration of $\mathrm{H}_{2} \mathrm{O}_{2}$, inset: electrode response at low concentration range (up to $0.25 \mathrm{mM} \mathrm{H}_{2} \mathrm{O}_{2}$ ).

The basic operational parameters of the modified electrode determined in $0.1 \mathrm{M}$ PBS over $\mathrm{pH}$ range $5.0-9.0$ at potential of $0 \mathrm{~V}$, are provided in Table 1. The linear dynamic range of the electrode signal also differs as dependent on the $\mathrm{pH}$ value of the buffer solution - the linearity of the signal, as well as the sensitivity, decreases as the $\mathrm{pH}$ value increasing over 6.0. The same effect was observed when increasing the acidity of the background electrolyte - at $\mathrm{pH} 5.0$ the dynamic range is shortened by $500 \mu \mathrm{M}$ (up to $5.0 \mathrm{mM} \mathrm{H}_{2} \mathrm{O}_{2}$ ) as compared to $\mathrm{pH}$ 6.0. 
The performance of the $\mathrm{Rh} / \mathrm{GC}$ catalyst, developed in this study, was compared with other modified electrodes. In Table 2 we have summarized various $\mathrm{H}_{2} \mathrm{O}_{2}$ sensors, based on modified glassy carbon electrodes, with respect to the applied potential and the sensitivity. All data presented are recorded in supporting electrolyte buffer solution with $\mathrm{pH}$ in the range $6.0-7.5$ in the $\mathrm{H}_{2} \mathrm{O}_{2}$ electroreduction mode. It can be seen that the proposed $\mathrm{Rh} / \mathrm{GC}$ electrode shows an excellent sensitivity, several times higher than that obtained by using other glassy carbon electrodes modified with metal or metal oxide particles.

\section{Conclusions}

The obtained rhodium-modified glassy carbon electrode exhibits fast and stable amperometric response, low detection limit $(4 \mu \mathrm{M})$ and wide linear range $(0.01-5.5 \mathrm{mM})$ for $\mathrm{H}_{2} \mathrm{O}_{2}$ detection at low applied potential $(0 \mathrm{~V}$ vs. $\mathrm{Ag} / \mathrm{AgCl})$. In addition, the working $\mathrm{pH}$-range $(5.0-7.0)$ and the high sensitivity of the electrode, makes it suitable transducer for studies with immobilized enzymes. The here presented catalyst provides a new approach to construct effective amperometric biosensor systems, based on oxidoreductases producing $\mathrm{H}_{2} \mathrm{O}_{2}$, for quantitative detection of biologically important compounds. Further experiments, such as the practical application of this modified electrode in real samples and the construction of biosensors, for high selective and sensitive bioanalysis, are underway.

Table 1. Operational parameters of modified electrode $\mathrm{Rh} / \mathrm{GC}$ at various $\mathrm{pH}$ values; applied potential of $0 \mathrm{~V}$; temperature $25^{\circ} \mathrm{C}$.

\begin{tabular}{cccc}
\hline $\mathbf{p H}$ & $\begin{array}{c}\text { Sensitivity, } \\
\boldsymbol{\mu} \mathbf{A} \mathbf{~ m M}^{-\mathbf{1}} \mathbf{c m}^{\mathbf{2}}\end{array}$ & $\mathbf{R}^{\mathbf{2}}$ & Linearity, $\mathbf{m M}$ \\
\hline 5.0 & 366 & 0.989 & 5.0 \\
6.0 & 377 & 0.987 & 5.5 \\
7.0 & 337 & 0.982 & 4.3 \\
8.0 & 96 & 0.987 & 4.0 \\
9.0 & 40 & 0.981 & 2.7
\end{tabular}

Table 2. Comparison of the electrode sensitivity of amperometric sensors for $\mathrm{H}_{2} \mathrm{O}_{2}$ detection, based on modified glassy carbon electrodes, with the achieved in the present work.

\begin{tabular}{|c|c|c|c|}
\hline Electrode modifier/(Electrode) & $\begin{array}{c}\text { Applied } \\
\text { potential, } \\
\mathrm{V}\end{array}$ & 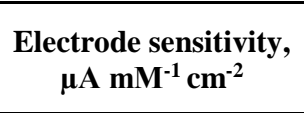 & Reference \\
\hline PtNW-CNT-CHIT/(GC) & $-0.1^{\mathrm{b}}$ & 260 & Qu et al. 2007 \\
\hline $\mathrm{Co}_{3} \mathrm{O}_{4}$ nanowalls/(GC) & $-0.2^{\mathrm{a}}$ & $80.74^{*}$ & Jia et al. 2009 \\
\hline $\mathrm{Ag} /(\mathrm{GC})$ & $-0.2^{a}$ & $104.53^{*}$ & Qin et al. 2011 \\
\hline PVA-MWCNTs-PtNPs/(GC) & $0^{\mathrm{a}}$ & 122.63 & Fang et al. 2012 \\
\hline Pd/PEDOT nanospheres/(GC) & $-0.2^{b}$ & 215.3 & Jiang et al. 2013 \\
\hline Graphene-AgNPLs/(GC) & $-0.5^{\mathrm{a}}$ & 183.5 & Zhong et al. 2013 \\
\hline $\mathrm{Rh} /(\mathrm{GC})$ & $0^{\mathrm{a}}$ & 377 & This work \\
\hline
\end{tabular}




\section{References}

Bartlett P., Marwan J. Preparation and characterization of H1e rhodium films. Microporous and Mesoporous Materials, 2003, 62(1-2): 73-79. https://doi.org/10.1016/S1387-1811(03)00394-9

Beyer H., K. Kohler K. NOx removal by rhodium catalysts supported on carbon nanotubes: Evidence for the stoichiometric reduction of $\mathrm{NO}_{2}$ and $\mathrm{NO}$ by the carbon support. Applied Catalysis B: Environmental, 2010, 96(12): $110-116$. https://doi.org/10.1016/j.apcatb.2010.02.008

Casella I., Contursi M. Highly dispersed rhodium particles on multi-walled carbon nanotubes for the electrochemical reduction of nitrate and nitrite ions in acid medium. ElectrochimicaActa,2014,138:447-453. https://doi.org/10.1016/j.electacta.2014.05.125

Dodevska T., Horozova E., Dimcheva N. Carbon electrodes modified with $\mathrm{Rh}$ : A comparative study of the catalytic activity in reduction of $\mathrm{H}_{2} \mathrm{O}_{2}$. Scientific Researches of the Union of Scientist of Bulgaria, Series C. Technics and Technologies, 2016, XIII: 20-23. [in Bulgarian]

Fang Y., Zhang D., Qin X., Miao Z., Takahashi S., Anzai J., Chen Q. A non-enzymatic hydrogen peroxide sensor based on poly(vinyl alcohol)-multiwalled carbon nanotubesplatinum nanoparticles hybrids modified glassy carbon electrode. Electrochimica Acta, 2012,70:266-271. https://doi.org/10.1016/j.electacta.2012.03.105

García S., Zhang L., Piburn G., Henkelman G., Humphrey S. Microwave synthesis of classically immiscible rhodiumsilver and rhodium-gold alloy nanoparticles: Highly active hydrogenation catalysts. ACS Nano, 2014, 8(11): 1151211521 . https://doi.org/10.1021/nn504746u

Horozova E.,Dimcheva N., Miteva M., Jordanova Z. Rhodium deposits on graphite: The impact of the graphite pad on the electrocatalytic activity in the electrooxidation of formic acid. Bulgarian Chemical Communications, 2008, 40(2): 129-136.

Jerkiewicz G., Borodzinski J. Relation between the surface states of oxide films at $\mathrm{Rh}$ electrodes and kinetics of the oxygen evolution reaction. Journal of the Chemical Society, FaradayTransactions, 1994,90:3669-3675. https://doi.org/10.1039/FT9949003669

Jia W., Guo M., Zheng Z., Yu T., Rodriguez E., Wang Y., Lei Y. Electrocatalytic oxidation and reduction of $\mathrm{H}_{2} \mathrm{O}_{2}$ on vertically aligned $\mathrm{Co}_{3} \mathrm{O}_{4}$ nanowalls electrode: Toward $\mathrm{H}_{2} \mathrm{O}_{2}$ detection. Journal of Electroanalytical Chemistry, 2009,625(1):27-32. https://doi.org/10.1016/j.jelechem.2008.09.020

Jiang F., Yue R., Du Y., Xu J., Yang P. A one-pot 'green' synthesis of Pd-decorated PEDOT nanospheres for nonenzymatic hydrogen peroxide sensing. Biosensors and Bioelectronics,2013,44:127-131.

https://doi.org/10.1016/j.bios.2013.01.003
Kanaru V., Humphrey S., Kyffin J., Jefferson D., Burton J., Ambruster M., Lambert R. Evidence for heterogeneous Sonogashira coupling of phenylacetylene and iodobenzene catalyzed by well defined rhodium nanoparticles. Dalton Transactions, 2009, 7602-7605. https://doi.org/10.1039/B912833F

Ortiz R., Marquez O. P., Marquez J., Gutierrez C. Spectroelectrochemical evaluation of $\mathrm{Rh}$ microparticles as electrocatalyst for carbon monoxide and formic acid oxidation. Portugaliae Electrochimica Acta, 2006, 24(1): 105-116.

Pallotta C., de Tacconi N., Arvia A. Potentiodynamic behaviour of the rhodium $/ \mathrm{H}_{2} \mathrm{SO}_{4}$ (aq) interface in the potential range of the hydrogen and oxygen electrosorption. ElectrochimicaActa, 1981,26(2):261-273. https://doi.org/10.1016/0013-4686(81)85012-8

Park K., Jang K., Kim H., Son S. Near-monodisperse tetrahedral rhodium nanoparticles on charcoal: The shapedependent catalytic hydrogenation of arenes. Angewandte Chemie International Edition, 2007, 46(7): 1152-1155. https://doi.org/10.1002/anie.200603961

Qin X., Wang H., Wang X., Miao Z., Fang Y., Chen Q., Shao $X$. Synthesis of dendritic silver nanostructures and their application in hydrogen peroxide electroreduction. Electrochimica Acta, 2011, 56(9): 3170-3174. https://doi.org/10.1016/j.electacta.2011.01.058

Qu F., Yang M., Shen G., Yu R. Electrochemical biosensing utilizing synergic action of carbon nanotubes and platinum nanowires prepared by template synthesis. Biosensors and Bioelectronics, 2007,22(8):1749-1755. https://doi.org/10.1016/j.bios.2006.08.003

Sathe B., Balan B., Pillai V. Enhanced electrocatalytic performance of interconnected $\mathrm{Rh}$ nano-chains towards formic acid oxidation. Energy and Environmental Science, 2011,4(3):1029-1036. http://dx.doi.org/10.1039/C0EE00219D

Villiard F., Jerkiewicz G. Comprehensive studies of formation and reduction of surface oxides at rhodium electrodes at 298 K. Canadian Journal of Chemistry, 1997, 75(11): 1656-1665. https://doi.org/10.1139/v97-197

Yuan Q., Zhou Z., Zhuang Z., Wang X. Tunable aqueous phase synthesis and shape-dependent electrochemical properties of rhodium nanostructures. Inorganic Chemistry, 2010, 49(12): 5515-5521. https://doi.org/10.1021/ic100249t

Zhong L., Gan S., Fu X., Li F., Han D., Guo L., Niu L. Electrochemically controlled growth of silver nanocrystals on graphene thin film and applications for efficient nonenzymatic $\mathrm{H}_{2} \mathrm{O}_{2}$ biosensor. Electrochimica Acta, 2013, 89:222-228. https://doi.org/10.1016/j.electacta.2012.10.161 